\title{
A STUDY OF THE GASTRIC SECRETION IN HYPERTHYROIDISM BEFORE AND AFTER OPERATION
}

\author{
By W. R. BERRYHILL AND HARLEY A. WILLIAMS
}

\section{(From the H. K. Cushing Laboratory of Experimental Medicine in the Department of Medicine of Western Reserve University and the Medical Service of Lakeside Hospital, Cleveland)}

(Received for publication April 2, 1932)

Gastric symptoms have long been associated with hyperthyroidism. The reports of studies attempting to correlate these symptoms with disturbances in gastric secretions are not uniform. Several investigators $(1,2)$ report an increase in the hydrochloric acid and total volume of secretion. One (3) contends there is no characteristic secretion in exophthalmic goiter. A greater number (4-16) report a diminution or absence of hydrochloric acid in hyperthyroidism and in the feeding of thyroid extracts to animals. Excellent reviews of the subject have appeared in recent papers by Moll and Flint (9), Brown (10), and Lerman and Means (13). With the development of a more accurate method for determining the degree of gastric acidity by histamine stimulation it seemed desirable to restudy the problem. Accordingly, a survey was begun eighteen months ago to determine the behavior of gastric secretion in hyperthyroidism before and after operation. Since the beginning of this work, Lerman and Means (13) have reported a study of gastric secretion in exophthalmic goiter before treatment using a similar method.

\section{METHOD}

The present generally accepted technique of gastric analysis was employed in this study. A fasting specimen was withdrawn, followed by the ingestion of $50 \mathrm{cc}$. of 7 per cent alcohol. Specimens were removed at twenty and forty minute intervals. If the last specimen contained no hydrochloric acid, histamine (ergotamine acid phosphate) $0.1 \mathrm{mgm}$. per ten kilograms was given subcutaneously and specimens were withdrawn at twenty and forty minute intervals. The volume, free hydrochloric acid and total acidity of each specimen were determined. Töpfer's reagent and phenolphthalein respectively were used as indicators and the results expressed as the number of cc. of N/10 $\mathrm{NaOH}$ necessary to neutralize $100 \mathrm{cc}$. of gastric juice.

Two analyses were done on each patient before preoperative iodine therapy was begun, a third the day before operation, and a fourth the day of discharge. The patients were followed by subsequent analyses at intervals of one to two months. We have arbitrarily classified the results upon the basis of the highest acid content obtained after the stimulation by alcohol and histamine: (1) Normals, those patients in whom repeated analyses showed free hydrochloric 
acid of $10 \mathrm{cc}$. or more with total acidity of $20 \mathrm{cc}$. or above. (2) Hypoacidity, those with free hydrochloric acid of $10 \mathrm{cc}$. or less and total acidity below $20 \mathrm{cc}$. (3) Achlorhydria, those with no hydrochloric acid 40 minutes after histamine stimulation.

\section{MATERIAL}

The gastric secretions of sixty-three patients with disease of the thyroid gland have been studied. Of these, nine had adenomatous goiters with normal function. One had an acute thyroiditis, also with normal function. Of the remaining fifty-three cases, thirty-five had exophthalmic goiter and fifteen had adenomas with elevated basal metabolism. The remaining three cases, which it seemed fair to exclude from this report; were complicated by conditions in which achlorhydria frequently occurs (pulmonary tuberculosis, diabetes mellitus, chronic alcohlolism). The ages of the patients ranged from sixteen to seventy-two with three below twenty years and three above sixty years. There were forty-five females and fifteen males.

\section{RESULTS}

\section{Gastric secretion in disease of thyroid gland before treatment}

A. Adenomatous goiters with normal function. Control observation on the nine cases with adenomatous goiters with normal function and the case with acute thyroiditis showed normal gastric acidity and volume of secretion.

B. Hyperthyroidism. Of the thirty-five patients with exophthalmic goiter, twenty-four or sixty-nine per cent had an achlorhydria before preoperative iodine therapy, eight an hypoacidity, and three a normal secretion. In the group of fifteen adenomatous goiters with hyperfunction ten or sixty-seven per cent showed no hydrochloric acid and the remaining five had an hypoacidity. Thus, for the group of fifty patients with hyperthyroidism, thirty-four or sixty-eight per cent had an achlorhydria and thirteen or twenty-six per cent had an hypoacidity. The diminution in volume of gastric secretion paralleled the diminished acid content in the cases with hypoacidity and achlorhydria.

The results of this study have been analyzed to determine whether there was any correlation between the incidence of achlorhydria and the age of the patient, the duration of the disease, or the elevation of metabolism. From the data in Tables I and II we have concluded that age plays no significant part in the occurrence of achlorhydria in hyperthyroidism. While it is true that the incidence of achlorhydria by age decades seemed to increase up to forty-five years; on the other hand when patients are divided into those above and those below the age of forty, sixty-nine per cent of twenty-six patients above forty years and sixtyseven per cent of the twenty-four patients under forty showed an absence of hydrochloric acid. The observation that the age of the patients with 
TABLE I

Incidence of achlorhydria and reappearance of $\mathrm{HCl}$ by age decades

\begin{tabular}{|c|c|c|c|c|c|c|c|c|c|c|c|c|}
\hline 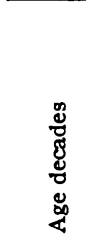 & 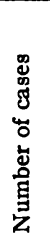 & 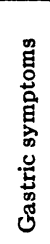 & 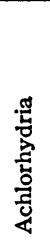 & 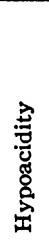 & $\begin{array}{l}\text { 五 } \\
\text { 宫 }\end{array}$ & 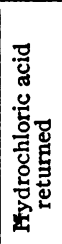 & 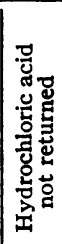 & 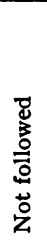 & 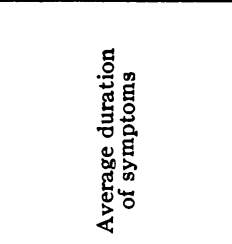 & 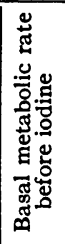 & 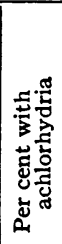 & 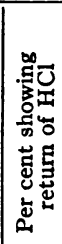 \\
\hline $\begin{array}{l}15-25 \\
26-35 \\
36-45 \\
46-55 \\
56-75\end{array}$ & $\begin{array}{r}9 \\
10 \\
14 \\
11 \\
6\end{array}$ & $\begin{array}{l}2 \\
4 \\
5 \\
5 \\
3\end{array}$ & $\begin{array}{r}4 \\
7 \\
14 \\
4 \\
5\end{array}$ & $\begin{array}{l}3 \\
3 \\
0 \\
6 \\
1\end{array}$ & $\begin{array}{l}2 \\
0 \\
0 \\
1 \\
0\end{array}$ & $\begin{array}{l}4 \\
3 \\
8 \\
2 \\
2\end{array}$ & $\begin{array}{l}0 \\
2 \\
4 \\
0 \\
1\end{array}$ & $\begin{array}{l}0 \\
2 \\
2 \\
2 \\
2\end{array}$ & $\begin{array}{l}8 \text { months } \\
12 \text { months } \\
10 \text { months } \\
1 \text { year, } 8 \text { months } \\
7 \text { years }\end{array}$ & $\begin{array}{l}55 \\
51 \\
49 \\
66 \\
44\end{array}$ & $\begin{array}{r}44 \\
70 \\
100 \\
36 \\
83\end{array}$ & $\begin{array}{r}100 \\
60 \\
67 \\
100 \\
67\end{array}$ \\
\hline & 50 & 19 & 34 & 13 & 3 & 19 & 7 & 8 & & & & \\
\hline
\end{tabular}

TABLE II

Incidence of achlorhydria and reappearance of $\mathrm{HCl}$ by age decades

\begin{tabular}{|c|c|c|c|c|c|c|c|c|c|c|}
\hline Age groups & 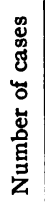 & 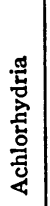 & 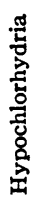 & 苋 & 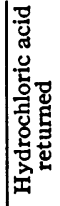 & 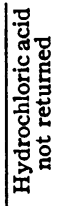 & 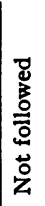 & 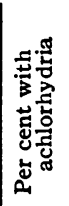 & 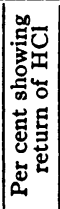 & Remarks \\
\hline $\begin{array}{l}\text { Under } 40 \ldots \ldots \ldots \ldots \ldots \ldots \\
\text { Over } 40 \ldots \ldots \ldots \ldots \ldots \ldots\end{array}$ & $\begin{array}{l}22 \\
13\end{array}$ & $\begin{array}{l}14 \\
10\end{array}$ & $\begin{array}{l}6 \\
2\end{array}$ & $\begin{array}{l}2 \\
1\end{array}$ & $\begin{array}{l}9 \\
7\end{array}$ & $\begin{array}{l}2 \\
2\end{array}$ & $\begin{array}{l}3 \\
2\end{array}$ & $\begin{array}{l}64 \\
77\end{array}$ & $\begin{array}{l}67 \\
70\end{array}$ & $\begin{array}{l}\text { Exophthalmic } \\
\text { goiters }\end{array}$ \\
\hline $\begin{array}{l}\text { Under } 40 \ldots \ldots \ldots \ldots \ldots \ldots \\
\text { Over } 40 \ldots \ldots \ldots \ldots \ldots\end{array}$ & $\begin{array}{r}2 \\
13\end{array}$ & $\begin{array}{l}2 \\
8\end{array}$ & $\begin{array}{l}0 \\
5\end{array}$ & $\begin{array}{l}0 \\
0\end{array}$ & $\begin{array}{l}1 \\
2\end{array}$ & $\begin{array}{l}1 \\
1\end{array}$ & $\begin{array}{l}0 \\
4\end{array}$ & $\begin{array}{l}100 \\
61.5\end{array}$ & $\begin{array}{l}50 \\
50\end{array}$ & $\begin{array}{l}\text { Adenomas with hy- } \\
\text { perfunction }\end{array}$ \\
\hline $\begin{array}{l}\text { Total for those under } 40 \ldots \\
\text { Total for those over } 40 \ldots \ldots\end{array}$ & $\begin{array}{l}24 \\
26\end{array}$ & $\begin{array}{l}16 \\
18\end{array}$ & $\begin{array}{l}6 \\
7\end{array}$ & $\begin{array}{l}2 \\
1\end{array}$ & $\begin{array}{r}10 \\
9\end{array}$ & $\begin{array}{l}3 \\
7\end{array}$ & $\begin{array}{l}3 \\
5\end{array}$ & $\begin{array}{l}67 \\
69\end{array}$ & $\begin{array}{l}76 \\
69\end{array}$ & $\begin{array}{l}\text { Exophthalmic goi- } \\
\text { ters and adenomas }\end{array}$ \\
\hline
\end{tabular}

hyperfunctioning adenomas as a group was higher than that of those with exophthalmic goiter, with practically the same percentage of achlorhydria in each group, is further evidence in support of this conclusion.

The duration of the hyperthyroidism does not appear to influence the incidence of achlorhydria. In Table III, it will be noted that sixty-nine per cent of thirteen cases with symptoms for two years and over had achlorhydria, while sixty-two per cent of twenty-six cases with symptoms of under one year's duration likewise had an absence of hydrochloric acid. Of the twenty-four patients with a history of more than one year's duration, eighteen had achlorhydria as against sixteen of twenty-six patients with a duration of disease of less than one year.

A similar lack of correlation was found between the incidence of achlorhydria and the elevation of metabolism (see Table IV). Of the 
TABLE III

Relation of incidence of achlorhydria to duration of the disease

\begin{tabular}{|c|c|c|c|c|c|c|c|c|c|c|c|c|}
\hline Duration of disease & 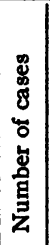 & 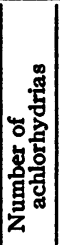 & 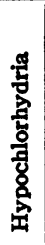 & 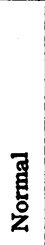 & 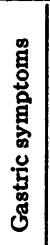 & 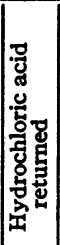 & 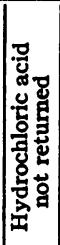 & 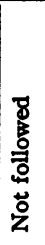 & 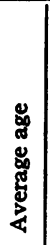 & 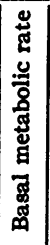 & 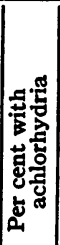 & 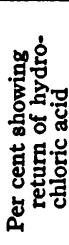 \\
\hline $\begin{array}{l}2 \text { years and over (average } 6 \text { years)... } \\
1 \text { to } 2 \text { years, } 19 \text { months duration..... } \\
\text { Under } 1 \text { year ( } 4 \text { months, average du- } \\
\text { ration) } \ldots \ldots \ldots \ldots \ldots \ldots \ldots\end{array}$ & $\begin{array}{l}13 \\
11 \\
26\end{array}$ & $\begin{array}{r}9 \\
9 \\
16\end{array}$ & $\begin{array}{l}4 \\
2 \\
7\end{array}$ & $\begin{array}{l}0 \\
0 \\
3\end{array}$ & $\begin{array}{r}4 \\
4 \\
11\end{array}$ & $\begin{array}{r}5 \\
3 \\
11\end{array}$ & $\begin{array}{l}1 \\
3 \\
3\end{array}$ & $\begin{array}{l}3 \\
3 \\
2\end{array}$ & $\begin{array}{l}53 \\
35 \\
36\end{array}$ & $\begin{array}{l}48 \\
59 \\
50\end{array}$ & $\begin{array}{l}69 \\
81 \\
62\end{array}$ & $\begin{array}{l}83 \\
50 \\
78.5\end{array}$ \\
\hline
\end{tabular}

TABLE IV

Height of metabolism

\begin{tabular}{|c|c|c|c|c|c|c|c|c|c|c|}
\hline $\begin{array}{l}\text { Basal } \\
\text { metabolic } \\
\text { rate }\end{array}$ & 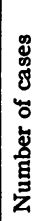 & 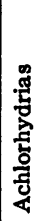 & 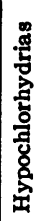 & 蛋 & 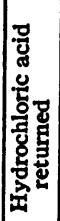 & 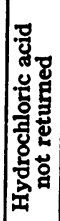 & 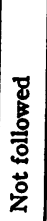 & 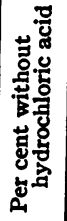 & 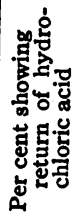 & \\
\hline $\begin{array}{c}\text { per cent } \\
\text { Under }+50 \ldots \ldots \ldots \ldots \\
\text { Over }+50 \ldots \ldots \ldots\end{array}$ & $\begin{array}{l}7 \\
8\end{array}$ & $\begin{array}{l}5 \\
5\end{array}$ & $\begin{array}{l}2 \\
3\end{array}$ & $\begin{array}{l}0 \\
0\end{array}$ & $\begin{array}{l}1 \\
2\end{array}$ & $\begin{array}{l}2 \\
1\end{array}$ & $\begin{array}{l}2 \\
2\end{array}$ & $\begin{array}{l}71 \\
62.5\end{array}$ & $\begin{array}{l}33.3 \\
66.6\end{array}$ & $\begin{array}{l}\text { Adenomas with hyper- } \\
\text { function }\end{array}$ \\
\hline $\begin{array}{l}\text { Under }+50 \ldots \ldots \ldots \\
\text { Over }+50 \ldots \ldots \ldots\end{array}$ & $\begin{array}{l}17 \\
18\end{array}$ & $\begin{array}{l}12 \\
12\end{array}$ & $\begin{array}{l}3 \\
5\end{array}$ & $\begin{array}{l}2 \\
1\end{array}$ & $\begin{array}{l}9 \\
7\end{array}$ & $\begin{array}{l}1 \\
3\end{array}$ & $\begin{array}{l}2 \\
2\end{array}$ & $\begin{array}{l}70 \\
67\end{array}$ & $\begin{array}{l}90 \\
70\end{array}$ & Exophthalmic goiters \\
\hline $\begin{array}{l}\text { Total under }+50 \ldots \\
\text { Total over }+50 \ldots\end{array}$ & $\begin{array}{l}24 \\
26\end{array}$ & $\begin{array}{l}17 \\
17\end{array}$ & $\begin{array}{l}5 \\
8\end{array}$ & $\begin{array}{l}2 \\
1\end{array}$ & $\begin{array}{r}10 \\
9\end{array}$ & $\begin{array}{l}3 \\
4\end{array}$ & $\begin{array}{l}4 \\
4\end{array}$ & $\begin{array}{l}70 \\
65\end{array}$ & $\begin{array}{l}77 \\
69\end{array}$ & $\begin{array}{l}\text { Adenomas with hyper- } \\
\text { function and exoph- } \\
\text { thalmic goiters }\end{array}$ \\
\hline
\end{tabular}

twenty-six patients with metabolic rate of plus fifty or higher before iodine medication, sixty-five had no hydrochloric acid; while seventy per cent of twenty-four patients with metabolism of less than plus fifty showed achlorhydria. The number of cases in each group is too small to permit of attributing much significance to the difference in percentage.

Of the fifty patients with hyperthyroidism, nineteen or thirty-eight per cent gave a history of gastric symptoms of a severe character. The most prominent of these were anorexia, vomiting after meals, periods of diarrhea, and abdominal pain. Of these nineteen patients, fourteen had achlorhydria.

\section{Gastric secretion in diseases of thyroid gland after treatment}

The study of gastric secretion was continued during preoperative therapy and for at least six months after operation in forty-two of the 
fifty patients with hyperthyroidism. In all the cases that have been followed, at least one subtotal thyroidectomy has been done, and each patient received preoperative iodine medication.

The gastric secretion was unchanged in two of the three patients with normal acidity before operation. The third had a persistence of hyperthyroidism and developed hypoacidity. The thirteen patients with hypoacidity before operation showed an increase in hydrochloric acid, total acidity and volume of secretion to normal after operation. Of the thirty-four patients with achlorhydria twenty-six were followed, twenty with exophthalmic goiters and six with hyperfunctioning adenomas. In eighty per cent of the former and in fifty per cent of the latter hydrochloric acid reappeared in the gastric secretion. Over a period of time we have been able to demonstrate a gradual increase in the hydrochloric acid, total acidity, and volume of secretion. In other words, seventy-three per cent of twenty-six patients in whom achlorhydria had previously been demonstrated showed a return of gastric secretion to a normal level following the therapeutic reduction of thyroid over-activity.

In thirty-two per cent of the cases, hydrochloric acid returned at the end of the preoperative iodine therapy. In sixteen per cent it was present ten days after operation. In the remaining fifty-two per cent it reappeared in from one to two months postoperative. With few exceptions the hydrochloric acid reappeared first, only after histamine stimulation, then after the alcohol meal, and finally in all specimens.

Of the seven cases in which achlorhydria has persisted after operation, one has a basal metabolism of plus fifty-two, while another has signs of myxedema. Excluding these two whose persisting anacidity may be associated with abnormal thyroid function, the percentage return of hydrochloric acid for the group is seventy-nine per cent.

The observation that the achlorhydria of hyperthyroidism is transient seemed of such significance that these cases were studied carefully in an attempt to correlate the reappearance of hydrochloric acid with various factors. The results have demonstrated that the secretory function of the stomach is resumed when the thyroid hyperfunction ceases, as indicated by a decrease in the pulse and metabolic rates to a normal level. There is no indication of any definite correlation between the return of hydrochloric acid and the total iodine dosage, age, duration of disease or elevation of metabolism. (See Tables III and IV.)

On the basis of these four factors there is no significant difference between those patients in whom gastric acidity returned to normal and those with a persisting achlorhydria. Excluding the eight patients not followed and the two in whom the persisting anacidity may still be associated with a continuation of thyroid disease, there is an incidence of achlorhydria for the group of ten per cent which is not higher than the incidence for normal individuals in this age group $(17,18)$. 


\section{DISCUSSION}

The results of this study clearly indicate that the gastric acidity in hyperthyroidism is markedly diminished. There is a high incidence of achlorhydria and hypoacidity irrespective of whether the hyperthyroidism is associated with exophthalmic goiter or with adenomatous goiter with hyperfunction. This latter finding is of particular value as previous investigators have reported that achlorhydria is either rare (5) or does not occur in adenomatous goiter with hyperfunction (8).

Achlorhydria was demonstrated in sixty-eight per cent of fifty cases, an incidence five times that in normal individuals of the same age (17). This is a definitely higher figure than most investigators have reported $(5,7,8,10)$ and is more nearly comparable to that found by Herzfeld (6) and Moore (11).

Contrary to previous reports $(8,10,13)$, our results indicate no relationship between the incidence of achlorhydria and the duration of the disease, height of the metabolism or age of the patient.

The most significant finding in this study has been the return of gastric secretion in the achlorhydrias of patients with hyperthyroidism after treatment. The reappearance of hydrochloric acid and the increase in gastric acidity and volume of secretion has not been demonstrated previously so far as we have been able to learn. Heimann (12) states that the secretory anomalies in hyperthyroid disease do not improve, but the evidence in support of this conclusion does not appear in his report. Our observation makes untenable several previously reported conclusions $(2,12,13)$ based on the assumption that the acid secreting impairment was permanent.

A high incidence of achlorhydria in hyperthyroidism is to be expected in the light of recent experimental work on the nervous control of the gastric glands $(19,20,21,22)$. Considerable evidence has accumulated which would indicate that this control may be the resultant of two antagonistic forces, the excitatory secretory in the parasympathetic nerves and the inhibitory secretory in the sympathetic. Whether the excessive stimulation of the secretory inhibitory nerves to the gastric glands by the thyroid hormones can, in itself, explain this pronounced disturbance in the gastric secretion; or whether other extra-thyroidal factors play a part, we are unable to say. It seems reasonable, however, to suppose that an autonomic nervous imbalance in thyroid hyperfunction may manifest itself locally in the stomach as well as generally throughout the body.

The return of gastric acidity after treatment is suggestive evidence that the thyroid overactivity plays a major rôle in the depression of gastric acidity. It follows that the gastric glands should resume their normal function upon the removal of thyroid hyperfunction if no structural damage has occurred in the mucosa of the stomach. That no permanent damage resulted must be inferred, at least in seventy-three per cent of the 
cases in this study. Heimann (12) concluded that the achlorhydria resulted from a direct toxic action of the thyroid hormone on the gastric glands. If this were true, the injury must of necessity be a temporary one, from which the glands easily recover.

If a predisposing constitutional element were involved as an extrathyroidal factor, the achlorhydria should persist. As already observed, however, the reappearance of $\mathrm{HCl}$ in patients with hyperthyroidism, who were known to have had an achlorhydria, has been as definite and clear cut as the increased tendency to achlorhydria.

A gastric analysis may be of some diagnostic value in differentiating between a mild or disguised hyperthyroidism and other diseases, particularly the neuroses.

\section{CONCLUSIONS}

1. The reported studies demonstrate that there is a high incidence of achlorhydria in hyperthyroidism.

2. Of fifty patients with hyperthyroidism, sixty-eight per cent had achlorhydria after histamine stimulation.

3. Achlorhydria was demonstrated in sixty-nine per cent of thirty-five patients with exophthalmic goiter, and in sixty-seven per cent of patients with hyperfunctioning adenomas.

4. Control studies on nine patients having adenomatous goiters with normal function of the thyroid, and on one patient with acute thyroiditis showed normal gastric acidity.

5. The gastric secretion has been studied for six months after operation in forty-two of the fifty cases of hyperthyroidism.

6. In seventy-three per cent of these the hydrochloric acid has returned in the gastric secretion and the total acidity has increased. The thirteen patients with hypoacidity before operation had a normal secretion after the thyroid overactivity ceased.

7. The results of this study support the belief that thyroid overactivity may play the major rôle in producing the diminished secretion of acid in hyperthyroidism.

\section{BIBLIOGRAPHY}

1. Neilson, C. H., J. Am. Med. Assoc., 1914, lxii, 434. Some Points in the Treatment of Hyperacidity, Especially with Reference to the Use of Hydrogen Dioxid.

2. Lewit, S. G., Ztschr. f. klin. Med., 1925, cii, 440. Schilddrüse und Magensekretion.

3. Boenheim, F., Arch. f. Verdauungskr., 1920, xxvi, 74 . Über den Einfluss von Blutdrusen-Extrakten auf die Magensekretion.

4. King, J. H., Med. Clin. N. Am., 1919, ii, 1655. Gastro-intestinal Disturbances in Metabolic Diseases and Diseases of the Ductless Glands.

5. Lockwood, B. C., J. Am. Med. Assoc., 1925, lxxxv, 1032. The Digestive Tract and Endocrine Function.

6. Herzfeld, E., Deutsche med. Wchnschr., 1923, xlix, 1436. Zur Magensekretion bei Morbus Basedowi. 
7. Keefer, C. S., and Bloomfield, A. L., Bull. Johns Hopkins Hosp., 1926, xxxix, 304. The Significance of Gastric Anacidity.

8. Moll, H., and Scott, R. A. M., Lancet, 1927, i, 68. Gastric Secretion in Graves' Disease.

9. Moll, H., and Flint, E. R., Brit. J. Surg., 1928, xvi, 283. The Depressive Influence of the Sympathetic Nerves on Gastric Acidity.

10. Brown, A., Ann. Surg., 1930, xcii, 321. The Influence of Hyperthyroidism . upon the Secretion of Free Hydrochloric Acid.

11. Moore, H., Brit. Med. J., 1930, i, 698. The Significance of Achlorhydria.

12. Heimann, F., Arch. f. Verdauungskr., 1931, xlix, 244. Über den Einfluss von Histamin auf die Aziditätsverhältnisse des Magens bei hyperthyreotischen Erkrankungen.

13. Lerman, J., and Means, J. H., J. Clin. Invest., 1932, xi, 167. The Gastric Secretion in Exophthalmic Goitre and Myxoedema.

14. Rogers, J., Rahe, J. M., and Ablahadian, E., Am. J. Physiol., 1919, xlviii, 79. The Stimulation and Inhibition of the Gastric Secretion Which Follows the Subcutaneous Administration of Certain Organ Extracts.

15. Truesdell, C., Am. J. Physiol., 1926, lxxvi, 20. The Effect of Feeding Thyroid Extract on Gastric Secretion.

16. Chang, H. C., and Sloan, J. H., Am. J. Physiol., 1927, lxxx, 732. The Influence of Experimental Hypothyroidism upon Gastric Secretion.

17. Vanzant, F. R., Proc. of Staff Meetings of Mayo Clinic, 1931, vi, 297. The Normal Range of Gastric Acidity from Youth to Old Age; an Analysis of 3,746 Records.

18. Lerman, J., Pierce, F. D., and Brogan, A. J., J. Clin. Invest., 1932, xi, 155. Gastric Acidity in Normal Individuals.

19. Keeton, R. W., Luckhardt, A. B., and Koch, F. C., Am. J. Physiol., 1920, li, 469. Gastrin Studies. IV. The Response of the Stomach Mucosa to Food and Gastrin Bodies as Influenced by Atropine.

20. Carlson, A. J., Physiol. Rev., 1923, iii, 1. The Secretion of Gastric Juice in Health and Disease.

21. Bickel, A., Klin. Wchnschr., 1925, iv, 538. Der Experimentelle Berweis für das Vorkommen inneren Hungers.

22. de Vecchi, P., Ann. of Surg., 1927, lxxxvi, 479. Effect of Section of the Vago Sympathetic Nerves of the Stomach upon the Secretion of Hydrochloric Acid in Gastric Juice. 